\title{
The Using Virtual Computer-Assisted Planning in Orthognathic Surgery: A Systematic Review and Meta-Analysis
}

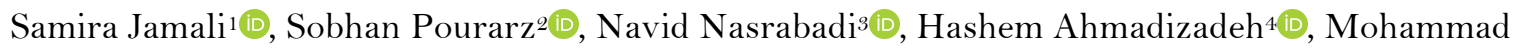 \\ Khorram $^{5}$ (D), Maryam Darvish 6 (D)
}

\begin{abstract}
${ }^{1}$ Department of Endodontics, Stomatological Hospital, College of Stomatology, Xi'an Jiaotong University, Shaanxi, PR China.

2Department of Oral and Maxillofacial Surgery, School of Dentistry, Isfahan University of Medical Sciences, Isfahan, Iran.

${ }^{3}$ Department of Endodontics, School of Dentistry, Shahid Beheshti University of Medical Sciences, Tehran, Iran. ${ }^{4}$ School of Dentistry, Tehran University of Medical Sciences, Tehran, Iran.

${ }^{5}$ Golpayegan Health Center, Isfahan University of Medical Sciences, Isfahan, Iran.

${ }^{6}$ Department of Endodontics, School of Dentistry, Kerman University of Medical Sciences, Kerman, Iran.
\end{abstract}

Author to whom correspondence should be addressed: Samira Jamali, Department of Endodontics, Stomatological Hospital, College of Stomatology, Xi'an Jiaotong University, Shaanxi 710004, PR China. Phone: +86 2982655450. E-mail: samira.jamali9o@yahoo.com.

Academic Editors: Alessandro Leite Cavalcanti and Wilton Wilney Nascimento Padilha

Received: 07 November 2019 / Accepted: 20 March 2020 / Published: 08 April 2020

How to cite this article: Jamali S, Pourarz S, Nasrabadi N, Ahmadizadeh H, Khorram M, Darvish M. The using virtual computer-assisted planning in orthognathic surgery: a systematic review and meta-analysis. Pesqui Bras Odontopediatria Clín Integr. 2020; 20:e5381. https://doi.org/10.1590/pboci.2020.064

\begin{abstract}
Objective: To use virtual computer-assisted planning in orthognathic surgeries through meta-analysis and systematic review. Material and Methods: This search took place between 2010 and 2019. The databases searched in this domain included MEDLINE, PubMed, Cochrane Library, Embase, ISI, and Google scholar. Accordingly, the abstracts of the articles were initially reviewed and the ones that had the most coordination with the study objectives were selected. Then, the full texts of the articles were examined; and finally, five studies were selected. In addition to reviewing the related literature, the results were extracted and entered into the meta-analyzer Stata V.14 to summarize the final results. Results: The sample size in this study was at a range from 6 to 28 patients and a total number of 85 patients had participated in the given investigations. As well, CT and CBCT were selected as imaging methods. Clinical imaging and analysis were also employed in computer-assisted planning in all five studies. Subsequently, surgical planning was performed and the virtual splint was designed while the planning time was 225 minutes and 145 minutes in two studies. Conclusion: The present results supported computer-assisted planning and the quality of scientific evidence.
\end{abstract}

Keywords: Orthognathic Surgery; Cone-Beam Computed Tomography; Diagnostic Imaging. 


\section{Introduction}

As a unique facial surgery, orthognathic surgery can significantly improve the patient's appearance and occlusal function and also affect the patient's sense of self and well-being. In modern orthognathic surgery, successful results depend on a close collaboration between orthodontists and surgeons in all treatment steps, ranging from preoperative planning to occlusion finalization [1].

The stone model surgery has been conventionally used to perform orthognathic surgery that involves mandible into stone models and translation of the desirable clinical movements of the maxilla, which are cut and then repositioned into the class-I occlusion that generate a splint. Despite being significantly timeconsuming, the model surgery is a reproducible and precise surgical method of correcting non-cleft patients as well as dentofacial skeleton in the cleft. Virtual surgical planning (VSP) and 3D imaging have also become popular in orthognathic surgery with the emergence of computed VSP, and tomography scanning is thus quickly replacing traditional model surgery in many regions of Iran and across the globe. So, whether or not the feasibility and application of virtual model surgery can obviate the need for conventional model surgery in both academic and private settings should be determined [2,3].

Recent decades have also witnessed the evolution of planning in orthognathic surgery [4]. Moreover, $3 \mathrm{D}$ virtual orthognathic planning has been proved as a cost-effective, reliable, and efficient alternative [4]. The widespread industrial applications of CAD/CAM technology have further generated both the desire and the momentum for the translation of $3 \mathrm{D}$ images into physical prototype models. Meanwhile, computed tomography (CT) imaging has introduced 3D anatomy of the living humans [5].

Over the past decades, the effect of the CAD/CAM technology, particularly the rapid prototyping (RP) technology, combined with the availability of 3D medical images, i.e., CT, medical image analysis software, and magnetic resonance imaging (MRI) have transformed clinical practices in craniomaxillofacial surgery. Nowadays, these applications range from customized fabricated craniofacial prosthetic implants to occlusal guides in orthognathic surgical procedures [6].

Therefore, the present systematic review and meta-analysis were conducted to evaluate the use of virtual computer-assisted planning in orthognathic surgery.

\section{Material and Methods}

The present systematic review followed the preferred reporting items for meta-analyses and systematic reviews as well as reporting guidelines. The study protocol was also developed via evaluating 8 selected studies systematically. In this regard, data extraction forms were developed after obtaining the initial results of the search.

\section{Search Strategy}

This search took place between 2010 and 2019. The databases searched for this purpose included Medline, PubMed, Cochrane Library, Embase, ISI, and Google scholar. To this end, the abstracts of the articles were initially reviewed and the ones that had the most coordination with the study objectives were selected. Then, the full-texts of the articles were examined and finally, 5 studies were selected (Figure 1).

\section{Inclusion Criteria}

The inclusion criteria were as follows: A sample size of at least 5; All clinical trials larger than case studies; Conventional orthognathic surgeries fulfilled to correct dental and facial development abnormalities; 
and Evaluation of accuracy and precision through comparing 3D virtual surgical plans with actual 3D surgical outcomes. Exclusion Criteria: Case reports involving below 5 patients; Surgeries performed using a distraction apparatus; and Surgeries associated with cancer, trauma, and cleft palate.

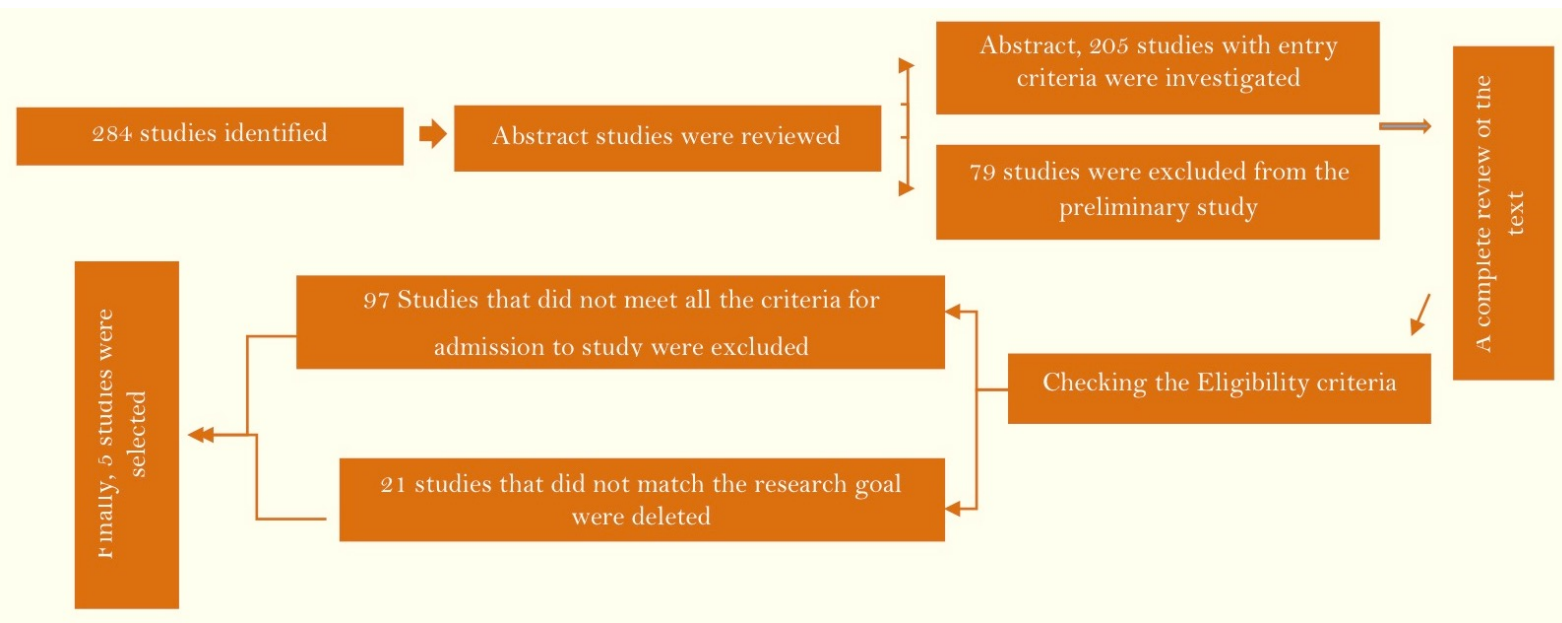

Figure 1. Study attrition diagram.

Data Extraction and Analysis Procedure

Evaluation the risk of bias - RCTs were surveyed utilizing the Cochrane Collaboration tool for evaluating risk of bias and the risk of bias of non-randomized studies was evaluated utilizing the methodological list for non-randomized studies. The subsequent data were extracted from the research included: study, years, number of patients, imaging of dental arches, software used for virtual planning, surgical splint, planning time, conclusions, postoperative period and mean of general, maxilla, mandible and mandibular condyle. Calculate the risk ratio (RR) and 95\% confidence interval (CI). Forest plots in metaanalysis assessed using a commercially available software program (Comprehensive Meta-Analysis Stata, V 14).

\section{Results}

In this study, the sample size was at a range from 6 to 28 patients and a total number of 85 patients had participated in the investigations. The imaging methods were CT and CBCT. Clinical imaging and analysis had also been used in computer-assisted planning in all the 5 studies [7-11]. Likewise, surgical planning had been performed and the virtual splint had been designed while the planning time was 225 minutes and 145 minutes in two studies (Table 1).

Moreover, the systematic review suggested the precision of computer-assisted planning in orthognathic surgery as follows (Table 2): 1. Maxilla: Sagittal<1 mm (1-0.14), Transversal<0.8 mm (0.8-0.04), Vertical: <1.2 mm (1.2-0.23); 2. Mandible: Sagittal<1.1 mm (1.1-0.13), Transversal<0.8 mm (0.8-0.17), Vertical<0.6 mm (0.6-0.33); 3. Chin: Sagittal<1 mm (1-0.3), Transversal<0.8 mm (0.8-0.76), Vertical: $<0.6 \mathrm{~mm}$ (0.6-0.25); 4. Mandibular condyle: Sagittal $<1 \mathrm{~mm}(0.18 \mathrm{~mm})$, Transversal $<0.8 \mathrm{~mm}(0.07)$, Vertical: $<0.6 \mathrm{~mm}$ $(0.13 \mathrm{~mm})$

The surgical splint in all 5 studies was surgical splint and the software used for virtual planning in two studies [7,10] was SimPlant OMS (Materialise, Leuven, Belgium). The postoperative period in two studies had lasted 3 months [7,11], and that was six weeks [8], 3 days [9], 6 months [10] in other investigations. Quality analysis of the studies included was illustrated in Tables 3 and 4 and Figure 2. 
Table 1. Computer-aided surgery-articles included in the review.

\begin{tabular}{|c|c|c|c|c|c|c|c|}
\hline Author & $\begin{array}{l}\text { Number of } \\
\text { Patients }\end{array}$ & $\begin{array}{l}\text { Imaging } \\
\text { Method }\end{array}$ & $\begin{array}{c}\text { Imaging of Dental } \\
\text { Arches }\end{array}$ & $\begin{array}{l}\text { Software Used for Virtual } \\
\text { Planning }\end{array}$ & $\begin{array}{l}\text { Surgical } \\
\text { Splint }\end{array}$ & $\begin{array}{l}\text { Planning } \\
\text { Time }\end{array}$ & Conclusions \\
\hline Centenero et al. [7] & 16 & $\begin{array}{l}\text { CT, } \\
\text { CBCT }\end{array}$ & $\begin{array}{l}\text { A scan of the plaster } \\
\text { model }\end{array}$ & 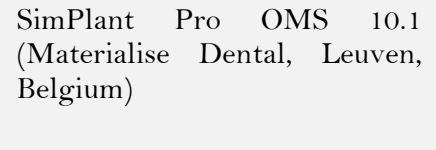 & Occlusal Splint & NA & $\begin{array}{l}\text { The Software program used in the study is } \\
\text { reliable for } 3 \mathrm{D} \text { planning and for the } \\
\text { manufacture of surgical splints using } \\
\text { CAD/CAM technology. }\end{array}$ \\
\hline Luebbers et al. [8] & 15 & CBCT & $\begin{array}{l}\text { A Scan of bite } \\
\text { registration with } \\
\text { reference points for } \\
\text { image fusion with CT }\end{array}$ & $\begin{array}{l}\text { Amira (Visage Imaging } \mathrm{GmbH} \text {, } \\
\text { Germany) }\end{array}$ & Occlusal Splint & $255 \mathrm{~min}$ & $\begin{array}{l}\text { The accuracy of the designed intermediate } \\
\text { splint met the requirements for bimaxillary } \\
\text { surgery under clinical circumstances. }\end{array}$ \\
\hline Li et al. [9] & 6 & CT & $\begin{array}{l}\mathrm{CT} \text { with bite } \\
\text { registration }\end{array}$ & $\begin{array}{l}\text { SurgiCase CMF } \quad 5.0 \\
\text { (Materialise, Leuven, Belgium) } \\
\text { Unigraphics NX } 7.5 \text { (Siemens } \\
\text { PLM Software, TX, USA) }\end{array}$ & $\begin{array}{l}\text { Occlusal Splint } \\
\text { Bone Splint } \\
\text { (Maxilla) }\end{array}$ & $145 \mathrm{~min}$ & $\begin{array}{l}\text { CAD/CAM templates provide a reliable } \\
\text { method for transfer of maxillary surgical } \\
\text { planning, which may be a useful alternative to } \\
\text { the intermediate splint technique. }\end{array}$ \\
\hline Zinser et al. [10] & 28 & $\begin{array}{l}\text { CT, } \\
\text { CBCT }\end{array}$ & $\begin{array}{l}\text { A scan of plaster } \\
\text { model }\end{array}$ & $\begin{array}{l}\text { SimPlant Pro OMS } 10.1 \\
\text { (Materialise Dental, Belgium) }\end{array}$ & $\begin{array}{l}\text { Occlusal Splint } \\
\text { Bone Splint }\end{array}$ & NA & $\begin{array}{l}\mathrm{CAD} / \mathrm{CAM} \text { splints and surgical navigation } \\
\text { provide a reliable, innovative, and precise } \\
\text { approach for the transfer of virtual } \\
\text { orthognathic planning. }\end{array}$ \\
\hline Shaheen et al. [11] & 20 & $\begin{array}{l}\text { CT, } \\
\text { CBCT }\end{array}$ & $\begin{array}{l}\text { Virtual 3D planning- } \\
\text { printing }\end{array}$ & $\begin{array}{l}\text { The software to design the } \\
\text { intermediate and final splints } \\
\text { (Proplan software-Materialise, } \\
\text { Leuven, Belgium). The } \\
\text { designed splints were printed } \\
\text { in biocompatible material using } \\
\text { Objet Connex } 350 \text { (Stratasys, } \\
\text { Eden Prairie, Minnesota, USA) } \\
\text { with slice thickness of } 0.03 \mathrm{~mm} \text {. }\end{array}$ & Occlusal Splint & NA & $\begin{array}{l}19 \text { out of the } 20 \text { intermediate digitally } 3 \mathrm{D} \\
\text { printed splints were clinically accepted }\end{array}$ \\
\hline
\end{tabular}

CT: Computed Tomography; CBCT: Cone Beam Computed Tomography; NA: No information provided by the authors. 


\section{Table 2. Orthognathic surgery accuracy of the studies included.}

\begin{tabular}{|c|c|c|c|c|c|c|}
\hline Study & $\begin{array}{l}\text { Postoperative } \\
\text { Period }\end{array}$ & $\begin{array}{c}\text { General } \\
\text { Mean (SD) }\end{array}$ & $\begin{array}{c}\text { Maxilla } \\
\text { Mean (SD) }\end{array}$ & $\begin{array}{l}\text { Mandible } \\
\text { Mean (SD) }\end{array}$ & $\begin{array}{c}\text { Chin } \\
\text { Mean (SD) }\end{array}$ & $\begin{array}{c}\text { Mandibular Condyle } \\
\text { Mean (SD) }\end{array}$ \\
\hline Centenero et al. [7] & 3 Months & $\begin{array}{l}\text { Soft tissue 0.7240.310 (0.053-0.970) } \\
\text { ICCa Angles: 0.8670.164 (0.624-0.970) } \\
\text { ICCa Lines: 0.6080.368 (0.053- 0.947) } \\
\text { ICCa Bone tissue 0.7220.246 (0.350-0.964) } \\
\text { ICCa Angles: } 0.6550 .249(0.350-0.910) \\
\text { ICCa Lines: } 0.9220 .059(0.880-0.964)\end{array}$ & $\begin{array}{c}\text { OcPl: } 0.375 \text { (0.178 to } 0.739) \\
\text { ICCa (FHP) }\end{array}$ & $\begin{array}{c}\text { MdPI: } 0.608 \text { (0.162 to 0.849) } \\
\text { ICCa (FHP) }\end{array}$ & $\begin{array}{l}\text { MdPl: } 0.608 \\
\text { (0.162 to } 0.849) \\
\text { ICCa }(\mathrm{FHP})\end{array}$ & NA \\
\hline Luebbers et al. [8] & 6 Weeks & NA & $\begin{array}{l}\text { Sagittal: } 0.50 .22 \mathrm{~mm} \text { (o to } 0.9) \\
\text { Vertical: } 0.570 .35 \mathrm{~mm}(0.2 \text { to } 1.4) \\
\text { Transversal: } 0.380 .35 \mathrm{~mm} \text { (o to } 1.3)\end{array}$ & NA & NA & NA \\
\hline Li et al. [9] & 3 Days & $<1 \mathrm{~mm}(0.03-1.7)$ & $<1 \mathrm{~mm}(0.03-1.7)$ & NA & NA & NA \\
\hline Zinser et al. $[10]$ & 6 Months & NA & $\begin{array}{l}\text { Sagittal: }<0.14 \mathrm{~mm}(\mathrm{VS}) \\
\text { Sagittal: }<0.61 \mathrm{~mm}(\mathrm{CS}) \\
\text { Vertical: }<0.23 \mathrm{~mm}(\mathrm{VS}) \\
\text { Vertical: }<1.3 \mathrm{~mm}(\mathrm{CS}) \\
\text { Transversal: }<0.04 \mathrm{~mm}(\mathrm{VS}) \\
\text { Transversal: }<0.43 \mathrm{~mm}(\mathrm{CS}) \\
\text { MxPl: } 0.358 \text { (FHP)-0.038 (MFP) (VS) } \\
\text { MxPl: } 0.638 \text { (FHP) } 0.468(\mathrm{MFP})(\mathrm{CS}) \\
\text { OcPl: } 0.028 \text { (FHP) } 0.038(\mathrm{MFP})(\mathrm{VS}) \\
\text { OcPl: } 0.958 \text { (FHP)-0.368 (MFP) (CS) } \\
\text { Soft Tissue Sagittal: }<1.39 \mathrm{~mm}(\mathrm{VS}) \\
\text { Sagittal: }<2.1 \mathrm{~mm}(\mathrm{CS}) \\
\text { Vertical: }<2.52 \mathrm{~mm}(\mathrm{VS}) \\
\text { Vertical: }<4.3 \mathrm{~mm}(\mathrm{CS}) \\
\text { Transversal: }<1.2 \mathrm{~mm}(\mathrm{VS}) \\
\text { Transversal: }<2.5 \mathrm{~mm}(\mathrm{CS})\end{array}$ & $\begin{array}{l}\text { Sagittal: }<0.17 \mathrm{~mm}(\mathrm{VS}) \\
\text { Sagittal: }<0.94 \mathrm{~mm}(\mathrm{CS}) \\
\text { Vertical: }<0.33 \mathrm{~mm}(\mathrm{VS}) \\
\text { Vertical: }<1.8 \mathrm{~mm}(\mathrm{CS}) \\
\text { Transversal: }<0.17 \mathrm{~mm}(\mathrm{VS}) \\
\text { Transversal: }<0.58 \mathrm{~mm}(\mathrm{CS}) \\
\text { MdPl: } 0.588 \text { (FHP) - 0.618 (MFP) } \\
\text { (VS) MdPl: } 10.258 \text { (FHP) - } 1.18 \\
\text { (MFP) (CS) } \\
\text { Soft Tissue Sagittal: 0.09 mm (VS) } \\
\text { Sagittal: } 0.74 \mathrm{~mm}(\mathrm{CS}) \\
\text { Vertical: }<0.48 \mathrm{~mm}(\mathrm{VS}) \\
\text { Vertical: } 1.5 \mathrm{~mm}(\mathrm{CS}) \\
\text { Transversal: } 1.1 \mathrm{~mm}(\mathrm{VS}) \\
\text { Transversal: } 1.3 \mathrm{~mm}(\mathrm{CS})\end{array}$ & NA & $\begin{array}{l}\text { Sagittal: } 0.18 \mathrm{~mm} \text { (VS) } \\
\text { Sagittal: } 0.61 \mathrm{~mm}(\mathrm{CS}) \\
\text { Vertical: } 0.13 \mathrm{~mm}(\mathrm{VS}) \\
\text { Vertical: } 0.5 \mathrm{~mm}(\mathrm{CS}) \\
\text { Transversal: } 0.07 \mathrm{~mm}(\mathrm{VS}) \\
\text { Transversal: } 0.5 \mathrm{~mm}(\mathrm{CS}) \\
\text { CoL-ZFS: } 0.058 \text { (VS) } \\
\text { CoL-ZFS: } 0.518(\mathrm{CS})\end{array}$ \\
\hline Shaheen et al. [11] & 3 Months & NA & OcPl: 0.275 (0.178 to 0.739$) \mathrm{ICCa}$ & NA & NA & NA \\
\hline
\end{tabular}

NA: No information provided by the authors; ICC: Intra-Class Correlation Coefficient; OcPl: Occlusal Plane; FHP: Frankfort Horizontal Plane; VS: Virtual Splint; CS: Classic Splint; MdP 1: Mandibular Plane; CoL: Condylar Line. 
Table 3. Quality analysis of the studies included.

\begin{tabular}{|c|c|c|c|c|c|}
\hline \multirow[t]{2}{*}{ Quality Criteria for Studies } & \multicolumn{5}{|c|}{ Study } \\
\hline & {$[7]$} & {$[8]$} & {$[9]$} & {$[10]$} & [11] \\
\hline Sample Randomization & No & No & No & No & No \\
\hline Comparison Between Treatments & No & No & No & Yes & No \\
\hline Blind Assessment & Yes & Yes & No & No & No \\
\hline Validation of Measurements & No & Yes & Yes & Yes & No \\
\hline Statistical Analysis & No & Yes & Yes & Yes & Yes \\
\hline Defined Inclusion and Exclusion Criteria & Yes & Yes & Yes & Yes & Yes \\
\hline Report on Follow-Up & Yes & Yes & Yes & Yes & Yes \\
\hline Risk of Bias Assessment & High & High & High & Medium & High \\
\hline
\end{tabular}

Risk of bias assessment: High $=0-5$ 'Yes'; Medium $=5-6$ 'Yes'; Low $=7$ 'Yes'.

Table 4. Studies selected for meta-analysis.

\begin{tabular}{llll}
\multicolumn{1}{c}{ Study } & \multicolumn{2}{c}{$9 \%$ Confidence Interval } & \% Weight \\
& Upper & Lower & \\
\hline Centenero et al. [7] & 10.800 & -8.800 & 22.78 \\
Luebbers et al. [8] & 11.800 & -7.800 & 22.78 \\
Li et al. [9] & 12.800 & -6.800 & 22.78 \\
Zinser et al. [10] & 15.760 & -7.760 & 15.82 \\
Shaheen et al. [11] & 16.760 & -6.760 & 15.82 \\
\hline
\end{tabular}

Heterogeneity Chi-squared $=0.33$ (d.f. $=4$ ), $\mathrm{p}=0.988 ;$ I-squared (variation in ES attributable to heterogeneity $)=0.0 \%$; Test of $\mathrm{ES}=0 ; \mathrm{z}=1.17, \mathrm{p}=0.242$.

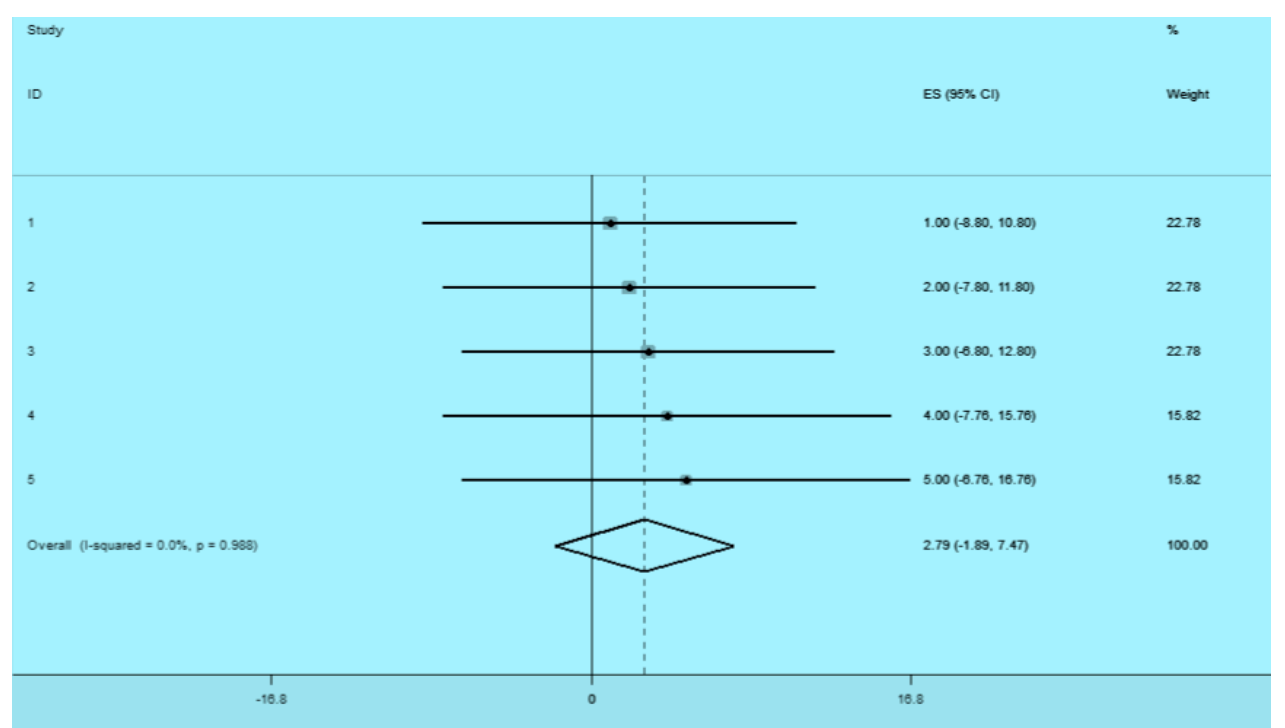

Figure 2. Forest plots showed evaluate virtual computer-assisted planning in orthognathic surgery.

\section{Discussion}

This study was performed using 3D planning to investigate the accuracy of SimPlant to Pro OMS 10.1 (Materialize, Leuven, Belgium) in terms of postoperative predictions and manufacture of surgical splints using the CAD/CAM technology. This program could help with diagnoses, as did other 3D virtual imaging systems [12].

In this regard, previous authors used CAD/CAM surgical splints to send $3 \mathrm{D}$ treatment plans to the CAD/CAM center and manufacture stereolithographic surgical splints [7]. The study software was comprised of algorithms to obtain the correct occlusion. The same study, as in the preoperative planning step, was also conducted on a group of patients 3 months after surgery, and the second set of DICOM-format images was derived using $\mathrm{CBCT}$ or $\mathrm{CT}$, which were transferred to the $\mathrm{CAD} / \mathrm{CAM}$ center wherein $3 \mathrm{D}$ images were 
obtained following segmentation, which enabled postoperative measurements to be contrasted with the predicted results acquired from the preoperative data. These authors used 3D planning as a working technique included in clinical practices. The next step in evaluating computerized 3D treatment planning was to use the CAD/CAM technology for manufacturing surgical splints used in orthognathic surgery, which could help in obtaining 3D physical structures from 3D images [13]. Some authors also argued that the given technique did not need traditional model surgery, recording of the CAD/CAM splint, and scanning of dental casts [9].

Furthermore, it has been suggested $3 \mathrm{D}$ planning and fabrication of intermediate splints for bimaxillary orthognathic surgery [11]. Other studies also confirmed these results [14,15]. In this regard, the designed intermediate splint was accurate enough to satisfy the requirements of bimaxillary surgery [8]. Moreover, the advantages of using 3D printing methods in orthognathic surgery included a precise translation of treatment plans, patient satisfaction, and optimal functional and aesthetic outcomes [16].

It should be noted that the precision of the maxilla translation was below $1 \mathrm{~mm}$ in computer-assisted planning for orthognathic surgery and the rotation was reported below $1.5 \mathrm{~mm}$ [17]. The vertical precision of the maxilla was found to be below $1.2 \mathrm{~mm}$ in 3D imaging [10]. The splints used also resembled those utilized by other authors $[9,10]$. The differences between the two interventions could be explained by the fact that surgical splints could not be used in classic planning and that surgeons were guided by their experiences as well as certain chin plate and internal reference points. Classic planning was, therefore, not precise enough in chin surgeries, and computer-assisted planning could yield higher accuracy levels [7].

\section{Conclusion}

The software program used in the investigations included in this study was found to be reliable enough for 3D planning as well as manufacturing surgical splints using CAD/CAM technology. These results supported computer-assisted planning and the quality of scientific evidence. Finally, it was recommended to conduct further randomized clinical trials on the present subject.

\section{Authors' Contributions}

\begin{tabular}{|c|c|c|}
\hline SJ & (iD) 0000-0003-3803-1235 & $\begin{array}{l}\text { Conceptualization, Methodology, Investigation, Formal Analysis, Writing - } \\
\text { Original Draft Preparation and Writing - Review and Editing. }\end{array}$ \\
\hline $\mathrm{SP}$ & (iD) $0000-0002-7900-3671$ & Writing - Review and Editing. \\
\hline $\mathrm{NN}$ & (iD) $0000-0002-6365-6619$ & Writing - Original Draft Preparation and Writing - Review and Editing. \\
\hline HA & (iD) $0000-0001-7845-2638$ & Writing - Review and Editing. \\
\hline MK & (iD) $0000-0001-8254-3129$ & Writing - Review and Editing. \\
\hline MD & (iD) $0000-0002-0622-4895$ & Formal Analysis and Writing - Original Draft Preparation. \\
\hline
\end{tabular}

\section{Financial Support}

None.

\section{Conflict of Interest}

The authors declare no conflicts of interest.

\section{References}

[1] Khechoyan DY. Orthognathic surgery: general considerations. Semin Plast Surg 2013; 27(3):133-6. https://doi.org/10.1055/s-0033-1357109 
[2] Hammoudeh JA, Howell LK, Boutros S, Scott MA, Urata MM. Current status of surgical planning for orthognathic surgery: traditional methods versus 3D surgical planning. Plast Reconstr Surg Glob Open 2015; 3(2):e307. https://doi.org/10.1097/GOX.0000000000000184

[3] Lee YC, Sohn HB, Kim SK, Bae OY, Lee JH. A novel method for the management of proximal segment using computer-assisted simulation surgery: correct condyle head positioning and better proximal segment placement. Maxillofac Plast Reconstr Surg 2015; 37(1):21. https://doi.org/10.1186/s40902-015-0023-3

[4] Hatamleh M, Turner C, Bhamrah G, Mack G, Osher J. Improved virtual planning for bimaxillary orthognathic surgery. J Craniofac Surg 2016; 27(6):e568-73. https://doi.org/10.1097/SCS.0000000000002877

[5] Zhao L, Patel PK, Cohen M. Application of virtual surgical planning with computer assisted design and manufacturing technology to craniomaxillofacial surgery. Arch Plast Surg 2012; 39:309-16.

[6] Eufinger H, Wehmöller M, Harders A, Heuser L. Prefabricated prostheses for the reconstruction of skull defects. Int J Oral Maxillofac Surg 1995;24(1):104-10. https://doi.org/10.1016/S0901-5027(05)80870-7

[7] Aboul-Hosn Centenero S, Hernández-Alfaro F. 3D planning in orthognathic surgery: CAD/CAM surgical splints and prediction of the soft and hard tissues results - our experience in 16 cases. J Craniomaxillofac Surg 2012; 4O(2):162-8. https://doi.org/10.1016/j.jcms.2011.03.014

[8] Sun Y, Luebbers HT, Agbaje JO, Schepers S, Vrielinck L, Lambrichts I, et al. Accuracy of upper jaw positioning with intermediate splint fabrication after virtual planning in bimaxillary orthognathic surgery. J Craniofac Surg 2013; 24(6):1871-6. https://doi.org/10.1097/SCS.ob013e31829a80d9

[9] Li B, Zhang L, Sun H, Yuan J, Shen SGF, Wang X. A novel method of computer-aided orthognathic surgery using individual CAD/CAM templates: a combination of the osteotomy and repositioning guides. Br J Oral Maxillofac Surg 2013; 51(8):e239-e44. https://doi.org/10.1016/j.bjoms.2013.03.007

[10] Zinser MJ, Sailer HF, Ritter L, Braumann B, Maegele M, Zöller JE. A paradigm shift in orthognathic surgery? A comparison of navigation, computer-aided designed/computer-aided manufactured splints, and "classic" intermaxillary splints to surgical transfer of virtual orthognathic planning. J Oral Maxillofac Surg 2013; 71(12):2 151.e1-21. https://doi.org/10.1016/j.joms.2013.07.007

[11] Shaheen E, Coopman R, Jacobs R, Politis C. Optimized 3D virtually planned intermediate splints for bimaxillary orthognathic surgery: a clinical validation study in 20 patients. J Craniomaxillofac Surg 2018; 46(9):1441-7. https://doi.org/10.1016/j.jcms.2018.05.050

[12] de Tejada MJBG, Hernández-Alfaro F, Maier D, Pagès CM. Planificación virtual y diseño de férulas CAD/CAM en cirugía ortognática: una nueva era? Rev Españ Ortod 2005; 35(4):363-70. [In Spanish].

[13] Gateno J, Xia JJ, Teichgraeber JF, Christensen AM, Lemoine JJ, Liebschner MA, et al. Clinical feasibility of computer-aided surgical simulation (CASS) in the treatment of complex cranio-maxillofacial deformities. $J$ Oral Maxillofac Surg 2007; 65(4):728-34. https://doi.org/10.1016/j.joms.2006.04.001

[14] Al-Rimawi A, EzEldeen M, Schneider D, Politis C, Jacobs R. 3D printed temporary veneer restoring autotransplanted teeth in children: design and concept validation ex vivo. Int J Environ Res Public Health 2019; 16(3):496. https://doi.org/10.3390/ijerph 16030496

[15] Zhou Z, Zhao H, Zhang S, Zheng J, Yang C. Evaluation of accuracy and sensory outcomes of mandibular reconstruction using computer-assisted surgical simulation. J Craniomaxillofac Surg 2019; 47(1):6-14. https://doi.org/10.1016/j.jcms.2018.10.002

[16] Lin HH, Lonic D, Lo LJ. 3D printing in orthognathic surgery - a literature review. J Formos Med Assoc 2018; $117(7): 547-58$. https://doi.org/10.1016/j.jfma.2018.01.008

[17] Hsu SS-P, Gateno J, Bell RB, Hirsch DL, Markiewicz MR, Teichgraeber JF, et al. Accuracy of a computer-aided surgical simulation protocol for orthognathic surgery: a prospective multicenter study. J Oral Maxillofac Surg 2013; 71(1):128-42. https://doi.org/10.1016/j.joms.2012.03.027 